\title{
MODELING AND SIMULATION OF-PUBLIC HOUSING CONSTRUCTION IN HONG KONG
}

\author{
Jonathan Jingsheng Shi \\ S. X. Zeng \\ C.M. Tam \\ Department of Building and Construction \\ City University of Hong Kong \\ 83 Tat Chee Ave., Kowloon, HONG KONG
}

\begin{abstract}
Hong Kong possesses one of the world's largest public housing stocks which provide accommodation for 3.1 million people. To meet the growing need for public housing, the government has committed to produce 50,000 public flat units (plus 35,000 units from private developers) a year as its long term housing policy. To meet this production target, contractors are facing with the challenge to further speed up the construction process. Currently, it takes 6 days to construct one floor, and some contractors can achieve one floor in 4 days. Studies are undertaking to explore the possibility of achieving one floor in two days. This paper focuses on the application of simulation technique for modeling and simulating public housing construction in Hong Kong with the intention to conclude the appropriate floor cycle construction time and necessary resource combination.
\end{abstract}

\section{INTRODUCTION}

Hong Kong has the most dynamic construction industry in the world. The remarkable speed of construction has developed a reputation, and is claimed to have only been achieved in Hong Kong. Public housing represents a very important aspect of the society. Public housing construction has already achieved a very impressive high speed. A public housing project with 40 stories takes less than two years to complete. The government has committed an ambitious annual production target of 50,000 public flat units to meet the growing need of its citizens. Contractors in Hong Kong are facing with the challenge to further speed up their public housing construction process.

Computer simulation can model a construction process on the operational level by considering the random nature, resource-driven characteristics and dynamic interactions during operation (Shi and AbouRizk 1997). It has been proven to be a very effective tool for planning and improving the performance of the real world construction operations (Halpin 1977 and Paulson et al 1987). Since the development of CYCLONE by Halpin (1977, 1990), construction simulation has been advancing with the computer technology. Various construction simulation languages have been developed. Research endeavor has also attempted to enhance construction modeling and simulation capacities such as DISCO (Huang et. al. 1994) and McCahill \& Bernold (1993), HSM (Sawhney and AbouRizk 1995), RBM (Shi and AbouRizk 1997). Successful applications of simulation in construction have been documented in Lansley (1986), Paulson et. al. (1987), Touran (1987), Vanegas (1993), Chau (1995), Dawood (1995), Smith et al (1995), and Shi and AbouRizk (1998).

With the complexity in public housing construction (Chan et al. 1995), simulation provides a sound technique for investigating the process in more detailed. This paper presents a study on modeling and simulating the public housing construction by considering the major resources and operations. The construction time of a typical floor cycle and utilization of resources will be highlighted.

\section{PUBLIC HOUSING IN HONG KONG}

Hong Kong possesses one of the world's largest public housing stocks that provide accommodation for half of its population, or 3.1 million people. These public housing stocks are allocated to its residents through renting or home ownership schemes. Two government bodies, the Housing Authority and Housing Society, are responsible for developing, allocating, and maintaining the public housing properties. According to the government prediction, Hong Kong will face a rapid growth of population in next twenty years. In order to meet the growing need for public housing, the Hong Kong government has established its long-term housing strategy, i.e. to produce 50,000 flat units from currently 35,000 units per year. 


\subsection{Floor Cycle Time}

Standardization is one of the many interesting features of public housing in Hong Kong. Currently public housing stocks are designed with 39 or 44 stories high to maximize land usage. Each floor has the same layout of four wings: A, B, C, and D as illustrated in Fig. 1 .

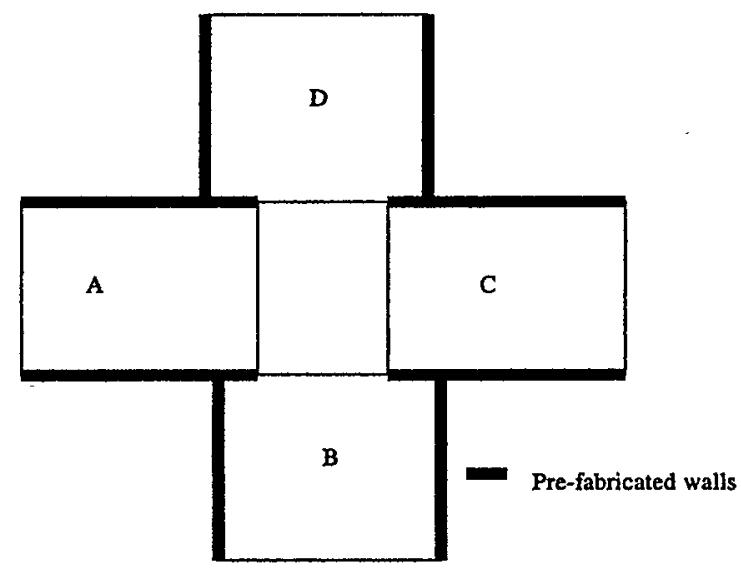

Figure 1: Floor Plan of Public.Housing

As many other housing projects, the duration of a public housing project is controlled by the construction of the framework structures of the building. Starting from level 2, the construction process is repetitive from one floor to next floor. The time required to construct one floor is called the floor cycle time. Although the floor cycle time varies from low floors to higher floors, site data show that the variations are minimal. It can be treated as an important indicator with respect to the project duration. As a matter of fact, contractors plan their site operations based on the cycle time. With the introduction of pre-fabrication and new construction methods, Hong Kong contractors have been able to reduce the floor cycle time from 8 days to 6 days. Recently, some contractors can complete-one floor cycle in 4 days. With the increased annual production target, the contractors are required to study the possibility of 2 days per floor cycle.

\subsection{Pre-fabricated Concrete Panels}

Pre-fabricated concrete panels are extensively used including external facade walls and semi-slabs. Eight pieces of these panels are used to form the entire non-bearing walls for each wing (four pieces on each side, see Fig. 1). These concrete panels are precasted off-site, and installed on site. In addition to time reduction, pre-fabrication also improves the quality by minimizing works in the air.

\subsection{Construction Resources}

Tower canes are extensively used in public housing construction in Hong Kong. Because of high-rising (e.g. 39 stories), tower canes are needed for many construction activities such as installing pre-fabricated panels and pouring concrete. Therefore, tower cranes are usually one of the controlling resources. One tower crane is used for 8day and 6-day floor cycle plans. Two tower cranes or the combination of one tower crane and one concrete pump are used for 4-day floor cycle plan.

Housing construction is labor intensive. Many special gangs or crews are needed, mainly including: installation gang (InsG), bar-fixing gang (BarG), concrete-placing gang (ConcG), and carpenter gang (CarpG). The five major types of resources and their functions are summarized in Table 1:

Table 1: Major Resources and Their Functions

\begin{tabular}{|c|c|c|}
\hline Name & Symbol & Required by activities \\
\hline Crane & Crane & $\begin{array}{l}\text { Lifting, installation of } \\
\text { façade walls and precast } \\
\text { semi-slabs, erection of } \\
\text { wall-forms, and placing } \\
\text { concrete. }\end{array}$ \\
\hline $\begin{array}{l}\text { Installation } \\
\text { gang }\end{array}$ & InsG & $\begin{array}{l}\text { Striking off wall-form, } \\
\text { erection of wall-form, and } \\
\text { installation of façade walls } \\
\text { and precast semi-slabs. }\end{array}$ \\
\hline $\begin{array}{l}\text { Bar-fixing } \\
\text { gang }\end{array}$ & BarG & $\begin{array}{l}\text { Fixing bar for walls and } \\
\text { slabs. }\end{array}$ \\
\hline $\begin{array}{l}\text { Concreting } \\
\text { gang }\end{array}$ & ConcG & $\begin{array}{l}\text { Placing concrete for walls } \\
\text { and slabs }\end{array}$ \\
\hline $\begin{array}{l}\text { Carpenter } \\
\text { gang }\end{array}$ & CarpG & Erecting timer forms \\
\hline
\end{tabular}

\section{SIMULATION STUDY}

As discussed in the previous section, the construction of each floor is a typical repetitive process. The six-day floor cycle is currently used in public housing projects by most contractors, and will be used as the basis in this study. A simulation model is studied to represent the construction process. A general simulation language named AweSim (Pritsker 1997) is employed to facilitate modeling and simulation. The cycle time and utilization of resources are then analyzed. Afterwards, cycle time reduction is explored by changing crew sizes. 


\subsection{Modeling the Construction Process of a Floor Cycle}

There are four wings on each floor. Wings $A$ and $C$ are identical, so are wings $\mathrm{B}$ and $\mathrm{D}$. After certain differences, all wings involve the same construction process. After investigating site operations and contractors' plans, the major construction activities are abstracted as listed in Table 2 for a floor cycle.

Table 2: Major construction activities

\begin{tabular}{|c|c|c|c|}
\hline No. & Symbol & Description & $\begin{array}{l}\text { Required } \\
\text { resources }\end{array}$ \\
\hline 1 & ETF & $\begin{array}{l}\text { Erecting timber } \\
\text { form for corridor }\end{array}$ & CarpG $^{*}$ \\
\hline 2 & EWF & $\begin{array}{l}\text { Erection of all- } \\
\text { form }\end{array}$ & Crane, InsG \\
\hline 3 & FBS & Fixing-bar for slab & BarG \\
\hline 4 & FBW & Fixing-bar for wall & BarG \\
\hline 5 & IFS & $\begin{array}{l}\text { Installation of } \\
\text { precast semi-slab }\end{array}$ & Crane, InsG \\
\hline 6 & IPW & $\begin{array}{l}\text { Installation of } \\
\text { façade wall }\end{array}$ & Crane, InsG \\
\hline 7 & LBF & $\begin{array}{l}\text { Lifting bracing } \\
\text { frame }\end{array}$ & Crane, BarG \\
\hline 8 & LBS & Lifting bar for slab & Crane, BarG \\
\hline 9 & LBW & Lifting bar for wall & Crane, BarG \\
\hline 10 & LWP & $\begin{array}{l}\text { Lifting working } \\
\text { platform }\end{array}$ & Crane, InsG \\
\hline 11 & PCS & $\begin{array}{l}\text { Placing concrete } \\
\text { for slab }\end{array}$ & $\begin{array}{l}\text { Crane, } \\
\text { ConcG }\end{array}$ \\
\hline 12 & PCW. & $\begin{array}{l}\text { Placing concrete } \\
\text { for wall }\end{array}$ & $\begin{array}{l}\text { Crane, } \\
\text { ConcG }\end{array}$ \\
\hline 13 & SWF & $\begin{array}{l}\text { Striking off wall- } \\
\text { form }\end{array}$ & InsG \\
\hline
\end{tabular}

See Table 1 for Resource Symbols

The 13 activities repeat in each of the four wings, which means a total of 52 activities for the entire floor construction. In the AweSim model, activities are labeled by:

$$
\text { Activity }_{i} \quad i=\operatorname{wing} A, B, C \text {, or } D
$$

Activity can be any of above 13 activities. For example, $P C W_{B}$ indicates placing concrete for wall at wing $\mathrm{B}$.

The major modeling elements are ACTIVITY, AWAIT, and FREE nodes (Pritsker 1997). AWAIT, and FREE nodes are used to allocate required resources before an activity starts and to free them after use.

The durations of these activities vary in a small range for different wings and are collected from contractors' performance. The logical sequence among these activities is based on contractors' site plans, which also determine the priorities for competing shared resources.

\subsection{Simulation results of the 6-day cycle}

If the resource capacities are given as identical sizes as the existing 6-day cycle plan as in Table 3, run the simulation model. The time to complete one floor cycle is 61 hours. Contractors use twelve working hours per day for planning 6-day cycle, which means that the 6-day cycle can actually be completed in five days without additional resources. Because there are four wings at each floor, it takes 1.5 days to complete one wing for the 6-day cycle. In other words, a crew simply repeats its work every 1.5 days. If the floor cycle time is reduced to five days, there is no a simple repetitive working pattern for a crew. Instead, the five-day cycle would require a different working plan every day for each gang. That is why contractors like 4-day cycle. They do one wing in one day, and each gang just repeats its work everyday.

Average utilization is defined as average unit of the resource in use during the entire simulation time. Its value is obtained from simulation and is listed in the last column of Table 3 .

Table 3: Resource Information

\begin{tabular}{lllll}
\hline No. & Name & Symbol & Size & Avg. util. \\
\hline 1 & Crane & Crane & 1 & 0.97 \\
2 & $\begin{array}{l}\text { Installation } \\
\text { gang }\end{array}$ & InsG & 8 & 2.47 \\
3 & $\begin{array}{l}\text { Bar-fixing } \\
\text { gang }\end{array}$ & BarG & 8 & 5.56 \\
4 & $\begin{array}{l}\text { Concreting } \\
\text { gang }\end{array}$ & ConcG & 5 & 1.82 \\
5 & $\begin{array}{l}\text { Carpenter } \\
\text { gang }\end{array}$ & CarpG & 3 & 0.71 \\
\hline
\end{tabular}

Results in Table 3 show that the crane is highly utilized (97\%). Approximately six (5.56) of the eight barfixing men are utilized. The utilization of other resources is very low.

The average utilization gives a general overview how a crew is utilized. We can also investigate the utilization process of each resource in order to get a detailed picture how a crew is utilized. Figure 2 plots the utilization of the five crews along the entire simulation time. 

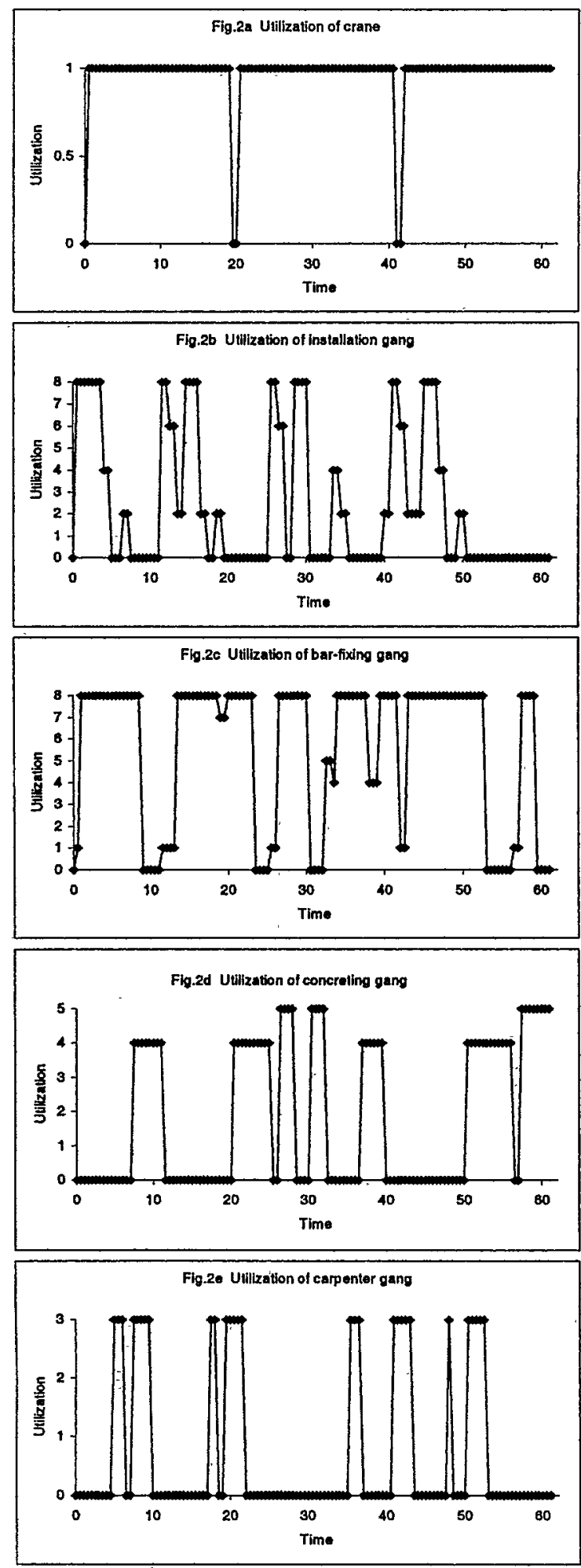

Figure 2 Utilization Process of Resources
Fig.2a indicates that the crane is mostly engaged except two short breaks. This confirms that the crane is the bottleneck of the construction process. In order to reduce the cycle time, crane's capacity should be increased or some duties should be assigned to other equipment, such as concrete pump for placing concrete.

Fig.2b shows that the installation gang, carpenter gang and concrete gang are seldom fully utilized, but bar-fixing is highly utilized most of the time.

\subsection{Sensitivity analysis}

As concluded previously that the crane is the controlling resource and the bar-fixing gang is also highly utilized, the capacity of crane is doubled to two and bar-fixing gang is increased from 8 to 10 .

Changing the capacities of the two resource blocks in the simulation model, run the model again. The new results can be obtained. The cycle time is reduced to 48.5 hours (i.e. 4 days). The average utilization of the gangs is listed in Table 4.

Table 4: Módified Resource Information

\begin{tabular}{lllll}
\hline No & Name & Symbol & Size & Avg. util. \\
\hline 1 & Crane & Crane & 2 & 1.23 \\
2 & Installation gang & InsG & 8 & 3.13 \\
3 & Bar-fixing gang & BarG & 10 & 7.11 \\
4 & Concreting gang & ConcG & 5 & 2.31 \\
5 & Carpenter gang & CarpG & 3 & 0.90 \\
\hline
\end{tabular}

The average utilization figures in Table 4 show that the utilization of cranes is reduced, but the utilization of other gangs has been improved.

The utilization processes of the five gangs are also plotted from Fig.3a through Fig.3e. These figures show that mostly one or two cranes are busy; the bar-fixing gang is still highly utilized most of the time; the other gangs are low utilized.

\section{CONCLUSION}

This paper studied simulation technique for modeling and simulating public housing construction in Hong Kong. The obtained results can not only show the floor cycle construction time but also highlight the utilization of resources. By increasing the capacities of the crane and the bar-fixing gang to 2 and 10 respectively, the floor cycle can be reduced to 4 days. The utilization of other resources is low. 

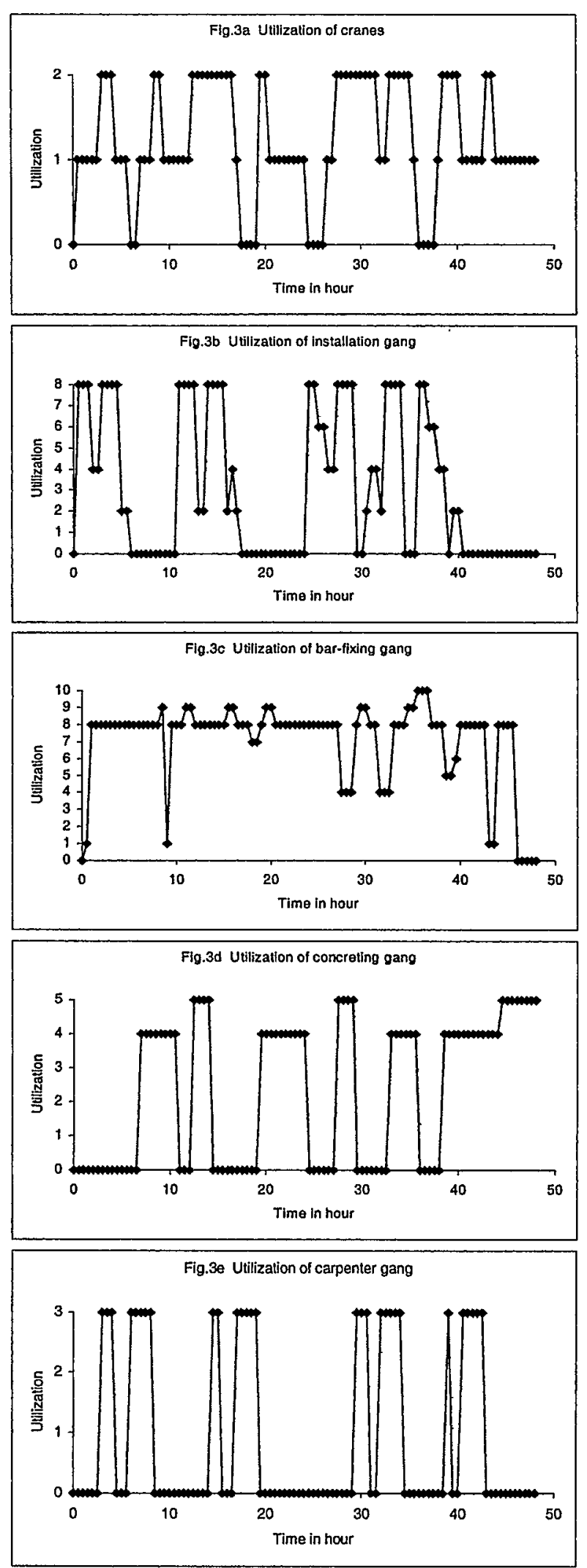

Figure 3: Utilization Process of Resources
Some more work is under way to enhance the simulation model by including detailed operations, such as installation of precasted concrete panels, placing concrete, and crane operations.

3-D animation and visualization are the promising technique to convince contractors about the simulation results. They also allow the user to experiment various construction methods on a computer and to design a new floor cycle plan (e.g. 2-day cycle). Integrating simulation results with animation and 3-D visualization is the remaining work of this study.

\section{REFERENCES}

Bernold, L. (1989). "Simulation of Nonsteady Construction Processes." J. Constr. Engrg. \& Mgmt., ASCE, June, 115(2), 163-178.

Chan, W.M and M. M. Kumaraswamy (1995). "A study of the factors affecting construction durations in Hong Kong." Construction Management and Economics, 13, 319-333.

Chau, K.W. (1995). "Monte Carlo Simulation of Construction Costs Using Subjective Data." Construction Management and Economics, 13, 369386.

Dawood, N. N. (1995). "An integrated knowledgebased/simulation approach to production planning: an application to the pre-cast industry." Construction Management and Economics, 13, 53-64.

Halpin, D.W. and Riggs, L. S. (1992). "Planning and Analysis of Construction Operations." John Wiley \& Sons, Inc., New York, N.W.

Huang, R., Grigoriadis, A.M, and Halpin, D.W. (1994). "Simulation of Cable-stayed bridges using DISCO." Proceedings of Winder Simulation Conference, 11301136.

Lansley, P.R. (1986). "Modelling Construction Organizations." Construction Management and Economics, 4, 19-36.

McCahill, D.F. and L.E. Bernold (1993). "ResourceOriented Modeling and Simulation in Construction." $J$. Constr. Engrg. \& Mgmt, ASCE, 119(3), 590-606.

Martinez, J. and loannou, P.J. (1994). "General purpose simulation with Stroboscope." Proceedings of Winter Simulation Conference, 1159-1166.

Paulson, B.C., Jr., Chan, W.T., Koo, C.C. (1987). "Construction Operations Simulation by Microcomputer." J. Constr. Engrg. \& Mgmt., ASCE, 113(2), 302-314.

Pritsker, A. A. B. (1997). Simulation with visual SLAM and AweSim. New York: Wiley, West Lafayette, Ind: Systems Pub. Corp.

Sawhney, A. and AbouRizk, S.M. (1995). "Simulation based planning method for construction project." $J$. Constr. Engrg. \& Mgmt, ASCE, 121(2), 297-303. 
Shi, J. And S. AbouRizk (1997). "Resource-based Modeling for Construction Simulation." J. Constr. Engrg. \& Mgmt, ASCE.

Shi, J. and S. AbouRizk (1998). "Continuous and Combined Event-process Models for Simulating Pipeline Construction." To appear in Construction Management and Economics.

Smith, S.D., Osborne, J.R. and Forde, M.C. (1995). "Analysis of Earth-moving Systems Using DiscreteEvent Simulation." J. Constr. Engrg. \& Mgmt, ASCE, 121(4), 388-396.

Tommelein, I. D., and A. M. Odeh (1994). "Knowledgebased Assembly of Simulation Networks Using Construction Designs, Plans, and Methods." Proceedings of the 1994 Winter Simulation Conference, 1145-1158.

Touran, A. (1987). "Simulation of Tunnel Operation", J. of Constr. Engrg. \& Mgmt., ASCE, 113(4), 554-568.

Vanegas, J.A., Bravo, E.B, and Halpin, D.W. (1993). "Simulation Technologies for Planning Heavy Construction Processes." J. Constr. Engrg. \& Mgmt., ASCE, 119(2), 336-354.

\section{AUTHOR BIOGRAPHIES}

JONATHAN JINGSHENG SHI is an Assistant Professor in the Department of Building and Construction at City University of Hong Kong. He received his Ph.D. in Civil Engineering from the University of Alberta in 1995. His research interests in simulation are focused on automated modeling, simulation, and optimization for construction. His other research interests include neural networks, construction scheduling and planning method, and construction productivity and improvement.

S.X. ZENG is a Ph.D. candidate at Herbin University of Architecture and Engineering. He is currently a Research Associate in the Department of Building and Construction of City University of Hong Kong. His research interests mainly include public housing construction, its policy and productivity improvement.

C.M. TAM is an Associate Professor in the Department of Building and Construction of City University of Hong Kong. Dr. Tam's research interests include construction safety, and information technology for construction. 